\title{
ANALYSIS OF FACTORS INFLUENCING THE EXISTENCE OF CULINARY VENDORS ON THE BEACH AREA AFTER 13 YEARS OF TSUNAMI (STUDY CASE : LAMPUUK BEACH, ACEH)
}

\author{
Zenitha Maulida, Dewi Rosa Indah \\ College of Economy Sabang (STIES) Banda Aceh \\ zenitha.abadi@gmail.com
}

\begin{abstract}
After 13 years of tsunami, Aceh has become one of tour destinations which offered various tours, especially Lampuuk beach tour. Recently, it has risen up from adversity. All tours area, especially Lampuuk beach tour progresses rapidly after tsunami. One of the tour developments was marked by growing and developing small-medium enterprises around the area which was currently more focused on culinary sector. In 2011, the Ministry of Tourism and Creative Economy included culinary as a subsector of creative economy. On the average, the culinary vendors built gazeboes to the visitors so that they could enjoy the scenery. The culinary provided by the traders was not luxurious, so it might be accepted by all society levels, starting from snacks to grilled fish as a typical menu of Aceh seashore. The goal of the study was to find out the factors supporting the existence of culinary vendors around Lampuuk Aceh beach tour after 13 years of tsunami which hit Aceh. The result showed that there were two dominant factors influencing the them. The first factor was the internal factors that consisted of the raw materials availability, the venture capital, simple material processing, labors, and turnover received factors, while the second one was the external factors, such as competitor's existence and vendors' retribution factors.
\end{abstract}

Keywords: Tourism, Culinary, Vendor, Lampuuk beach.

\section{INTRODUCTION}

Tourism based economic empowerment is able to improve the welfare of the surrounding society which is marked by the increase of the society income and the optimization of the empowerment through the advantages possessed by the region. The economic empowerment can be encouraged by concerning the advantages. Each region has its own special and various advantages. Banda Aceh, the province capital surrounded by beautiful beaches, has a tremendous potential in the field of beach tour. Lampuuk, one of the most popular white sand beach tours, usually experiences the peak of visitors on the weekends. It, the coastal area of Aceh Besar, has the worst affected area of the tsunami. Houses and settlements destroyed, facilities and infrastructure devastated on the tsunami disaster 13 years ago.

At present, Aceh, especially Lampuuk beach has risen up from adversity. All the tours area in the surrounding of the 
beach progresses rapidly after tsunami. Before tsunami, the beach had been also one of the interesting beach tours to be visited. However, the management had not been so good. Then after tsunami, by the inclusion of various material or nonmaterial assistance, it provides the area to become one of beach tour destinations that must be visited.

One of the tour developments is marked by growing and developing smallmedium enterprises around the area which is currently more focused on culinary sector. In 2011, the Ministry of Tourism and Creative Economy included culinary as a subsector of creative economy. On the average, the culinary vendors build gazeboes near the shore to the visitors so that they feel more freely. The culinary provided by the them is not luxurious, but it can be accepted by all society levels, starting from snacks, friend and boiled instant noodles to grilled fish as a typical menu of the Aceh seashore.

After 10 years of tsunami, the enterprises grow very rapidly; even the initial identification said that there were enterprises which have existed before tsunami, continued, and survived until now,. The identification also found the factors influencing the vendors survived, as the availability of venture capital, raw materials, their income, and retribution till 13 years of the disaster.

Based on the explanation above, the writer was interested in conducting the study about factors of the existence of culinary vendors around the beach on the economic empowerment of the society entitled "Analysis of Factors Influencing the Existence of Culinary Vendors on the Beach Area after 13 Years of Tsunami (Study Case: Lampuuk Beach, Aceh)"

\subsection{Research Problem}

The main problem disussed in this study was the factors which support the existence of culinary vendor around
Lampuuk Aceh tour after 13 years of tsunami disaster.

\subsection{Aim of Study}

This study was conducted to find out the factors supporting the existence of culinary vendors around Lampuuk Aceh tour after 13 years of tsunami disaster which hit Aceh.

\subsection{The Use of Study}

1. To find out the factors supporting the existence of culinary vendors around Lampuuk Aceh.

2. To suggest the government or private sector to promote the tour sector as a form of empowering the society around the beach.

\section{LITERATURE REVIEW}

\subsection{Tour}

Tourism is a trip undertaken for recreation of vacation and also the preparation for this activity. World Tourism Organization defines "tourist" is a person who travels at least $80 \mathrm{~km}$ (50 miles) from his house for recreational purpose. Many countries rely on the tourism industry as a source of income tax to the company which sells service to the tourists. Therefore, the development of tourism industry is one of the strategies used by NonGovernment Organization to promote certain areas as tour areas to increase the trade through goods and services sale for the non-local people.

Based on Law No. 10/2009 about Tourism, it is various kinds of tour activities supported by many facilities and services and provided by society, entrepreneur, Central and Local Government. The tourist attraction is anything that has the uniqueness, beauty, and value in the form of diversity of natural wealth of culture and man-made products which become the target or goal of tourist visit. Tourism 
Destination is a geographical area within one or more administrative areas which has the tourist attraction.

\subsection{Beach Tour}

The definition of beach tour can be found in the Law of Republic of Indonesia No.9 of 1990 about tourism. It is a travel activity conducted voluntarily and temporarily. Beach is a border between land and sea, while sea is a large pool of water which divides the land over the continents and islands. Thus, beach tour can be defined as a tour that utilizes natural resource potential and its supporting components, both natural and artificial or combination of them.

\subsection{Existence}

Here are some definitions of word "existence" written in the Great Indonesian Dictionary (KBBI) : (1) Staying in place (position, etc); Not moving (backward, etc); (2) Defending himself (against attack, temptation, etc); (3) Not willing to give up; having strong determination; having hard-hearted, (4) Enough for some time. The analysis of culinary vendors' existence means how capable they are to defend themselves, not give up, and stay in the same place in terms of business location and in the same culinary field.

\subsection{Culinary}

Currently, definition of term "culinary" is often heard and read through newspaper and audio visual. The term increasingly widespread in Indonesia on a television show that was guided by Bondan Winarno with his maknyus slogan. The Culinary definition cannot be separated from cooking activity that is closely related to daily food consumption. It can also be interpreted as processed products in the form of dishes such as side dish, food and drink. The word culinary is an absorption element of English which relates to cooking activity, while people who are working in culinary field are called chef.

Culinary tour is a blend of enjoying food while enjoying a travel atmosphere, relax, or vacation so it utilizes the time to the places that provides the typical food. In other words, the culinary term can be described freely without eliminating the meaning of blend between travelling while looking for typical food. Nowadays, it has become a lifestyle that cannot be separated with daily life because food is one of daily needs. All of them require a tasty food processing.

\section{RESEARCH METHOD}

\subsection{Research Location and Object}

The study took place in Lampuuk beach tour, Aceh Besar while the research object was the factors influencing the existence of culinary vendors around the beach to the empowerment of the society economy after 13 years of tsunami.

\subsection{Sampling Method}

Sampling method conducted is by using random sampling method and taking 30 respondents. According to Wirawan, 2002 in Mustika dan Apriliani (2013 : 122), this number was choosen because the minimum requirement for the sample amounted to the unknown population is as much 30 respondents.

\subsection{Type and Source of Data}

The study used qualitative data which is obtanied either directly (primary) or indirectly (secondary) from the research respondents. Data obtained directly from respondents (primer) based on the interview conducted to the culinary vendors in the surrounding of Lampuuk beach which taken as the sample, while data obtained indirectly (secondary) were various sources of literature, as 
journal, article, and other research results.

\section{RESULT AND DISCUSSION}

\subsection{Lampuuk Beach Tour}

Lampuuk beach was one of Aceh Besar's tour icons before tsunami occurred in 2004. The beach was always full of visitors from Banda Aceh, Meulaboh, or other regions. It had white sand and shady pine trees. This place became an appropriate place to relieve fatigue. When tsunami occurred, the beach which was approximately 15 kilometers from Banda Aceh suffered quite severe damage. The beachfront hotels and settlements were destroyed by huge waves. More than half of the population died in the disaster. The trauma to the threat of tsunami made people felt reluctant to stay near the beach because many pine trees collapsed and left debris of tsunami. This made the beach was closed for tourism activities. However, the beach gradually recovered. Approximately, a year after tsunami, the tourism activities started to be crowded. In the rehabilitation and reconstruction process after tsunami, the management of Lampuuk beach was integrated with several other tour objects in Aceh, like Weh island, Laut Tawar lake, and Takengon plateau.

This had a positive effect on the effort to restore Lampuuk beach as Aceh's tour icon. Not only local tourists, but also many NGO activists and foreign volunteers stopped by to try the tour beach, especially surfing. It boosted the popularity of the beach. Currently, the tour has fully recovered. There are four entrances which can be passed by the visitors to the different beach sections, namely Babah Satu, Babah Dua, Babah Tiga, and Babah Empat. Each entrance is named sequentially according to the positions, from the southernmost to the northernmost. Generally the entrances that the most visitors passed are Babah
Satu dan Babah Dua. The foreign tourists usually come from Babah Tiga. The location was usually used to surfing or relaxing to enjoy summer vacation activities. Along with the improvements made, it has been equipped with many tourism facilities, as banana boat. For visitors who want to spend the night, there are also various lodgings from guesthouse to cottage class. The fare is varied in accordance with the services and facilities desired.

In addition, the visitors who want to fill their stomach can also easily find the seafood stalls. The stalls offered a variety grilled fish dishes, such as snapper, grouper, pomfret, shrimp, squid, and others. The delicious grilled seafood is suitable to be enjoyed as a dish while spending a quality time with family or friends. It is more complete because it is equipped with fresh coconut water.

\subsection{Research Description}

The government's economic development and empowerment program is an answer of society needs that can minimize the poverty level of local society. One of the solutions was by developing the creative economy sector of culinary field. In 2011, the Ministry of Tourism and Creative Culinary included culinary as a creative economy subsector. In Indonesia, the term culinary became a public discussion in 2005 after a "Wisata Kuliner" television program showed the unique or well-reputed restaurants and became Indonesian's favorite program.

Aceh has a very attractive and exotic beach tour center, namely Lampuuk beach. The beach is located in the western of Aceh, precisely in Lhoknga District, Aceh Besar. It offers a wide range of reaction options, such as beach games, beauty of nature, and the typical culinary in the Aceh seashore. The culinary enterprises in the surrounding of the beach had been established before 
tsunami in 2004. Due to the access limitation of people who cannot travel, the enterprises had not developed because of Aceh's conditions had not conducive yet before the MoU of Peace in 2005 . In 2008, it was precisely when the beach re-opened at night after tsunami in 2004. There were several of business owners who could not afford to rebuild the business wheel after the disaster.

In this study, it was obtained the information from interview result with the head of local village that the number of gazeboes existed along the beach as many 75 enterprises. Each enterprise has 18 gazeboes that were used as tourists' rest place. The owners came from 5 villages in Lhoknga settlement, Lampuuk district, Aceh Besar. The entrepreneurs were mostly Lampuuk's indigenous or migrant residents who married with the indigenous residents. Every enterprise offered a variety of seashore typical culinary. Local culinary diversity provided in the surrounding of the gazeboes was really appetizing, like Aceh's fried/ boiled noodles, grilled fish, cold coconut water, Aceh's coffee, and so on.

Every day, the number of visitors are about 100 to 200 people on weekdays and 500 - 1000 people on weekends which make the business owners can earn the turnover around Rp. 500.000, to Rp. 1.000.000, on weekdays and Rp. 1.000.000, to Rp. 3.000.000, on weekends, even they can get the turnover about Rp. 10.000.000, in the certain moments, such as new year.

\subsection{Factors Influencing the Existence of Vendors}

The interview results gained by the researcher obtained that there is only a cottage business that can survive, namely "Awak Awai." There were many factors which made the food vendor still exist. They were because of the availability of fund, easy and simple raw materials, and another factor so that Awak Awai cottage becomes a pioneer of Aceh's seashore culinary and is wellknown by many people.

Based on further identification, observation, and in-depth interview, the factors influencing the existence of cottage and culinary vendors around the beach conducted by the researcher toward 30 culinary and cottage entrepreneurs, they were found that there were some factors influencing them which was divided into 2 main factors; internal and external factors.

The internal factors could be divided into 5 factors which consisted of the availability of raw materials, the ease of funding, simple materials processing, labors, and turnover received. On the other hand, there are 2 external factors, namely competitors' existence and vendors' retribution in the form of hygiene retribution.

The availability of raw materials became the first factor affecting the existence of vendors. It was caused by the raw materials were easily obtained because it was directly adjacent with the sea as the source of materials and also found in the markets near the beach. The location of material supply was affordable so that it was easier to shop.

The ease of funding was the second factor affecting the vendors. It was one of the considerations of them to be able to survive on their culinary and cottage business which was visited by domestic or foreign tourists.

The next factor was the process of simple materials processing that affected the existence of them. Based on observation and interview result, the entrepreneurs did not have any difficulties on processing the raw materials, especially fried/ boiled noodle which was easily obtained and grilled fish which was simple but it was really delicious to eat.

The labors factor also influenced the existence of the vendors around 
Lampuuk beach, Aceh Besar. According to the observation and interview, the entrepreneurs did not experience any problem because they recruited their family, even the local young men who need a job. A friendly, fast, and responsive waiter also affected their existence on this business.

The next factor was the turnover gained. The culinary business became a business opportunity that brought a big and undefeatable turnover. The habit of people who like to eat outside while enjoying the beauty of Lampuuk beach could be a new business opportunity to gain the big turnover so that they could survive running their business.

In addition, the first external factor affecting the existence of culinary and cottage vendors around the beach was the effect of competitors' existence. In any business, the entrepreneurs should notice the competitors' existence factor that provided the same culinary and progressed rapidly. Although they admitted having the regular customers who would not switch to other places, but they should create something different in managing their business well, both product innovation and price competition.

Vendors' retribution was also the external factor in the form of hygiene retribution influencing their existence. The hygiene retribution picked up by the local residents was aimed to clean the leftovers of food, such as food waste or coconut shells. According to the interview, Mrs. Nurlela, the culinary/ cottage entrepreneur, said that the hygiene retribution was not burdensome. The price collected was about $\mathrm{Rp}$. 10.000 , per day. It was also comparable with the waste cleaned and kept the livestock of local residents away from the cottage land. The food waste itself was utilized by the residents to feed their livestock.

Based on the factors above, the first factors were competitors and vendors retribution which was called external factors. In addition, the internal factors consisted of the raw materials availability, venture capital, process of simple materials processing, labors, and turnover received. All those factors could be interpreted that the existence of culinary entrepreneurs around Lampuuk beach became one of the local society empowerment to improve their economy prosperity in the surrounding of Lampuuk Beach, Aceh Besar.

\subsection{Managerial Implication: Strategy Development}

Before tsunami in 2004, Lampuuk beach was one of tour icon of Aceh Besar district which was full of the visitors from various regions. The white sand and shady pine trees made this place became a suitable place to relieve fatigue. After 10 years of tsunami, the beach recovered gradually and showed the better improvement that could be seen from tourism facilities offered to the visitors. This thing surely provided a positive effect toward the improvement of local society's economy. It was equal with the development of concept strategy, the management strategy also developed along with historical journey, both profit and non-profit organization. It was said that Strategy Management is "process or series of decision-making activity which is fundamental and comprehensive, also determination about the way to conduct it made by the top management and implemented by all levels within an organization to reach the goal." (Nawawi, 2005:148).

The definition of development is an attempt to improve technical, theoretical, conceptual, and moral ability of employees in accordance with job/ position need through education and training. The aim of tourism area developments are: (a) increasing the region and private sectors' participation on tourism development; (b) Enlarging the positive impact of development; and 
(c) Facilitating the control of environmental impact. The concept of tour area development is developed from the region's needs to increase its function and role in managing tourism, social life, economy, culture, education, society's welfare. By developing the area, it is expected that the tour area can be promoted maximally. According to various definitions of development, it can be concluded that the word "development" is a process, way, or act which aims to improve, expand or enhance.

The local residents were quite smart to find business opportunity. They opened a stall that offered grilled fish and seafood and also cottages which directly faced to the sea, vendors who offered the typical snacks or fruit from the region, as keranji fruit, rental of banana boat equipments, lodges or bungalows on the mountain as well as parking lot.

In the effort of Lampuuk beach tourism development, some strategies are implemented to improve the entrepreneurs' and local residents' prosperity, there are:

1. Strategy of area development

In this strategy, it is expected local government's cooperation and business actors to develop the tourism area which has not been reached before, such as adding playground, lodge, and restaurant so that there will be many places that the visitors can visit and ensure the region's safety so that those things can be a priority for the investors in investing. Memorandum-of Understanding of Aceh is expected to be able to awaken the tourism investors' and developers' desire to invest their asset in this tourism field.

2. Strategy of object and tour attraction development

In this strategy, the region government tries to make the beach as an icon of beach tour in Banda Aceh and the surrounding areas. One of them is by repairing Golf Seulawah field which had the background of sea view idolized by tourists, but it has left the memory, providing banana boat facilities, establishing more bungalows which has an affordable price and good quality so that the all domestic and foreign visitors can enjoy the situation adjusted with their money. The local government should also approach to the society to make they are more aware of maintaining the discipline and sustainability of Lampuuk beach tour.

3. Strategy of Promotion Development One of the ways to attract the tourists is by promoting the tour products or objects widely. In promoting the tour object, the local government made kite-flying festival in Lampuuk area. The festival was attended by the participants from 11 countries. It was part of program series of Visit Banda Aceh Year 2011. It was expected that the government could hold these events every year to increase the visitors to the Lampuuk beach tourism which provided an impact of the entrepreneurs' prosperity increase. During the promotion, it was only word of mount from the visitors' experience that came. They recommended the beauty of Lampuuk beach to others. By the existence of technology, many people could write the beauty of the beach as a fun and unforgettable experience and post it to the internet. Those things can also be an affordable promotion method. Generally, the existence of foreign investors in Aceh is an entrance and promotion facility to answer the challenge of Lampuuk beach tourism development. 
4. Strategy of facility and infrastructure development

The local government should develop facility and infrastructure in Lampuuk beach so that the number of domestic and foreign tourists increases. Not only facility and infrastructure, but also the transportation must be concerned. There are facilities that have already existed in Lampuuk beach area, like clean public toilets, food stalls, many trash cans, and janitors so that it is completely clean from cottages garbage which spreads around the beach. There is also a huge white mosque near the beach. It is the only building that still remains intact when tsunami happened in 2006 and be appointed by the government as a monument of tsunami tragedy. It is also located in the same area with post-tsunami housing built as an assistance of Turkey government.

The strategies above are expected to be able to be implemented better as a basis of business strategy. It is aimed to answer the challenge of Lampuuk beach tourism development and increase the welfare of all tourism business actors and society in the surrounding of Lampuuk generally.

\section{CONCLUSION}

This study discussed the factors influencing the defense of culinary

\section{REFERENCES}

Anoraga, Pandji. (2000). Manajeman Bisnis. Jakarta : PT. Rineka Cipta

Nawawi, Hadari. (2005). Manajemen Strategik. Yogyakarta: Gadjah Mada Pers traders in the Lampuuk beach area by concluding as follows:

1. Internal factors consist of:

- Raw materials

- Venture capital

- Process of simple material processing

- Labors, and

- Turnover received

2. External factors consist of:

- Competitors' existence

- Vendors' retribution.

\section{Suggestions}

Based on the conclusions above, it is required the suggestion, as follows:

1. The culinary entrepreneurs in the Lampuuk beach area should promote more intensely so that the consumers, both domestic and foreign tourists are interested in tasting the culinary typical, includes presentation and service to increase the business turnover.

2. The culinary entrepreneurs' existence should be supported by the local government policy in the field of fund and land provision, and promotion.

3. It should hold an event as a promotion facility, such as holding festival in the beach tour area that will introduce the coastal typical culinary and tour beach to a variety of levels to increase tourists' awareness.

Mustika, Apriliani. (2013), Analisis Faktor-Faktor yang mempengaruhi Kebertahanan Pedagang Kuliner Tradisional di Kabuaten Klungkung. JEKT.6 (2) : 118-127 
Maulida, Zenitha, Dewi Rosa Indah, Ferdi Nazirun Sijabat (2015). Analysis On The Impact of The Development of Lamphuuk Beach As The Tourism Location In Aceh Against Business Doers' Welfare and Society Around The Beach After 10 Years Tsunami. JASR 2015 - 5 (7) -349-356
Sukardi, (2003), Metodologi Penelitian Pendidikan. Jakarta.

Kurniyati, Zeny. (2007), Strategi Pengembangan Wisata Pantai Kartini Di Kabupaten Jepara. Jurnal penelitian , Fisip, Undip

Website (2015) : http//: parekraf.go.id 